九州大学学術情報リポジトリ

Kyushu University Institutional Repository

\title{
Analysis of the Scroll Compressor Changing into an Expander for Small Scale Power Plants Using an Organic Rankine Cycle System
}

Mus limm, Muswar

Department of Mechanical Engineering, Faculty of Engineering, Universitas Indonesia

Muhammad Idrus Alhamid

Department of Mechanical Engineering, Faculty of Engineering, Universitas Indonesia

Nasrudd in

Department of Mechanical Engineering, Faculty of Engineering, Universitas Indonesia

Ismoyo, Budi

Department of Mechanical Engineering, Faculty of Engineering, Universitas Indonesia

https://doi.org/10.5109/4150515

出版情報：Evergreen. 7 (4)，pp.615-620，2020-12. 九州大学グリーンテクノロジー研究教育センター バージョン：

権利関係 : 


\title{
Analysis of the Scroll Compressor Changing into an Expander for Small Scale Power Plants Using an Organic Rankine Cycle System
}

\author{
Muswar Muslim $^{1,2 *}$, Muhammad Idrus Alhamid ${ }^{1}$, Nasruddin $^{1}$, Budi Ismoyo ${ }^{1}$ \\ ${ }^{1)}$ Department of Mechanical Engineering, Faculty of Engineering, Universitas Indonesia, Kampus UI Depok, \\ Depok 16424, West Java, Indonesia \\ ${ }^{2)}$ Department of Marine System Engineering, Faculty of Marine Technology, Universitas Darma Persada, Pondok \\ Kelapa, Duren Sawit, Jakarta Timur 13450, DKI Jakarta, Indonesia \\ *Author to whom correspondence should be addressed: \\ *muswar_2000@yahoo.com
}

(Received November 4, 2020; Revised December 10, 2020; accepted December 16, 2020).

\begin{abstract}
Wastes from engineering components are difficult to recycle. According to previous studies, several waste enginering components can be used to produce small-scale power plants. Therefore, this research aims to modify cooling cars compressor into an expander (turbine) which is used in an Organic Rankine Cycle (ORC) system power generator. The ORC main components used in this research are the expanders, evaporator, condenser, and working fluid pump. The compressor used in place of the expander is TRSE09 type Sanden brand with a capacity of $0.5 \mathrm{hp}$. The experimental results showed that the expander rotation is between $1650-2750 \mathrm{rpm}$, with a $2.5-4.45 \%$ thermal efficiency.
\end{abstract}

\section{Keywords: Condensor, Evaporator, Expander, Organic Rankine Cycle, Scroll Compressor}

\section{Introduction}

Presently, the need for renewable energy power generation is rapidly increasing with the development of several technologies from many resources, such as solar, biomass, geothermal, and ocean. Other technology that is getting research attention is small-scale Organic Rankine Cycle (ORC) for power generator that can be used in remote areas.

Many studies have been carried out in ORC Technolgy. For instance, Simone A et al. ${ }^{1)}$ conducted a research that uses a combustion-engine heat source as input. Sorawit $\mathrm{S}$ et al. ${ }^{2}$ also used a solar collector as a heat source in developing an ORC main component. Guoquan Q et al. ${ }^{3)}$ carried out similar research using biomass as a heat source for ORC generators by converting the working fluid into steam. Meanwhile, Wolfgang $\mathrm{R}$ et al. ${ }^{4)}$ examined ORC using geothermal as a heat source to vaporize the working fluid. In addition, several studies utilized the waste heat from an internal combustion engine (ICE) for the ORC system. This was applied in solar, geothermal, and biomass energies ${ }^{6,7,8)}$. Also, ORC technology is also suitable and applicable to other heat sources, such as Ocean power generation due to the differences in seawater temperature. It is commonly called Ocean Thermal Energy Conversion (OTEC), Desalination System (Making Fresh Water), and power plants using a compression cooling system modification. The expander is one of the ORC components that can be classified into two types. Firstly based on their velocity such as axial and radial flow, and secondly as a positive displacement, namely scroll thread, and piston ${ }^{9,10,11)}$. Many small-scale ORC expanders have been used in several systems due to its exponential rotation speed in recent years. However, it is relatively more expensive for commercial purposes ${ }^{13)}$. Platell et al. ${ }^{14)}$ compared the positive expander with other types using a small-scale unit to determine the component parts displacement. Similarly, Muswar et al. ${ }^{15)}$ used a drum vessel consisting of a heater and heat exchanger as a heat production source for ORC. Meanwhile, M. Sharma et al. ${ }^{16)}$ used an expander as a turbine with an inlet temperature of $150{ }^{\circ} \mathrm{C}$, while $\mathrm{P}$. Animest et al. ${ }^{17}$ ) discussed $\mathrm{CO}^{2}$ as a medium in environmentally friendly experiments. Furthermore, M.I. Alhamid et al. ${ }^{18)}$ examined the cooling tower efficiency for the equipment, especially condenser components, as a coolant to liquefy the working fluid. This device can operate using working fluids types similar to those conducted by M.A. Islam et al. ${ }^{19)}$ and M.T.Kibria et al. ${ }^{20)}$. This research converted heat from renewable energy sources to electricity using Organic Rankine Cycle (ORC) technology. Some of the most important components used in this system are the evaporator, condenser, working fluid pump, expanders, and other supporting components. Furthermore, this research focuses on the expander, which acts as the main component that activates the generator to generate electricity. The expander is a modified version of the scroll-type vehicle air conditioner compressor, with the output designed to produce rotation and energy efficiency. 


\section{Methodology of Research}

This methodology describes the experimental process of operating a car scroll air conditioning (AC) as an expander in the ORC system. This experiment was carried out by planning, selecting, assembling, testing, measuring, calculating, and analyzing the system. These stages are shown in Figure 1.

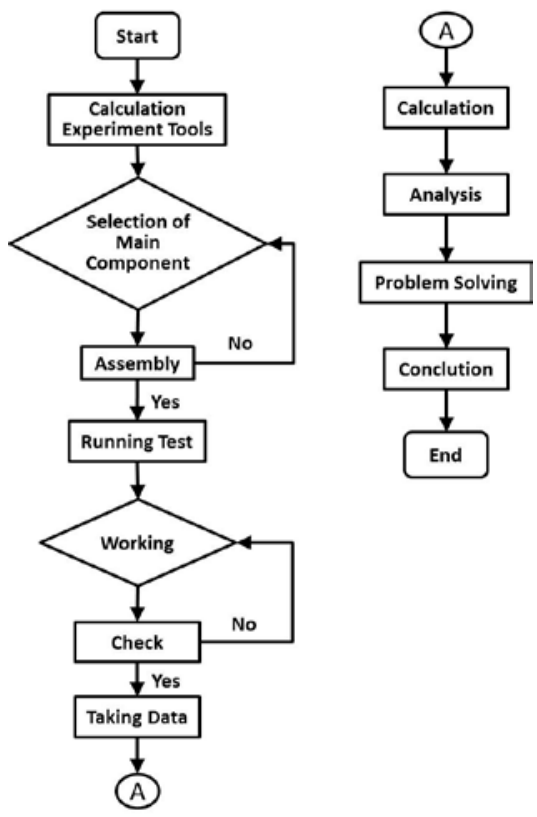

Fig. 1. Experiment Step of ORC System Power Generation

Figure 2 shows an experimental diagram of an ORC small-scale power plant. It indicates that the main components are evaporator, expander, condenser, fluid pump, etc.

\section{The Power Generation of Organic Rankine Cycle}

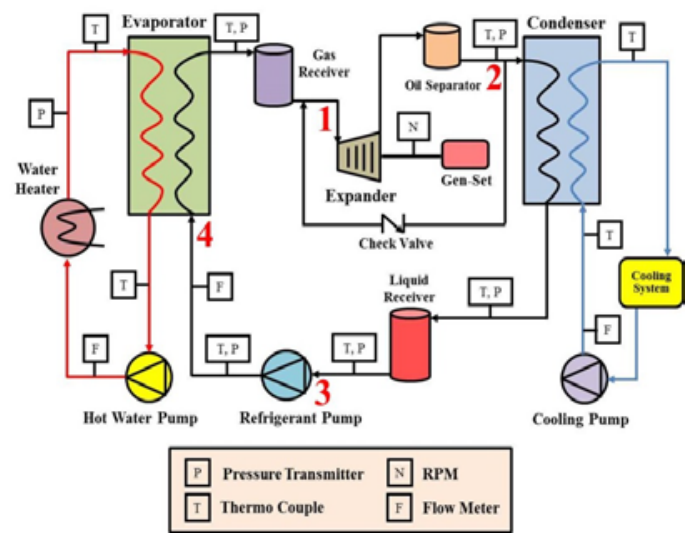

Figure 2. Diagram of the ORC System Experimental

In figure 2, number 1 is used to denote an expander. It is the main component used to couple the generator to produce electricity. Furthermore, the number 2 is the condenser, which acts as a heat exchanger. It lowers the temperature and changes the working fluid R-134a phase. At number 3 is the pump used to circulate the working fluid. Finally, the number 4 is the evaporator, which acts as a heat exchanger to evaporate the working fluid. The experimental data is calculated using the following equations.

$$
W_{\text {exp }}=\dot{m}\left(h_{1}-h_{2}\right)
$$

Equation 1 is the power output of expander $\mathrm{W}_{\text {exp. }}$ It produces by the mass flow rate of fluid after leaving the heat exchanger (evaporator) and the delta enthalpy from inlet and outlet of the expander.

$$
W_{\text {pump }}=\dot{m}\left(h_{4}-h_{3}\right)
$$

Equation 2 shows that the heat transfer energy is carried out in the condenser, thereby changing the the working fluid phase liquid.

$$
Q_{\text {in }}=\dot{m}\left(h_{1}-h_{4}\right)
$$

Equation 3 shows that the working fluid flow is sucked in by the pump and flows to the heat exchanger to change working fluid phase from liquid into vapor.

$$
Q_{\text {out }}=\dot{m}\left(h_{2}-h_{3}\right)
$$

Equation 4 shows that the incoming energy generated by the heat exchangeris the maximum steam produced, as shown in $\mathrm{Q}_{\mathrm{hw}}$.

$$
\eta_{t h}=\left(h_{4}-h_{3}\right) /\left(h_{1}-h_{2}\right)
$$

Equation 5 shows the thermal efficiency of the system due to the work process between the ratio of the pump operation and the expander. The experimental devices used in this research is shown in Figure 3.

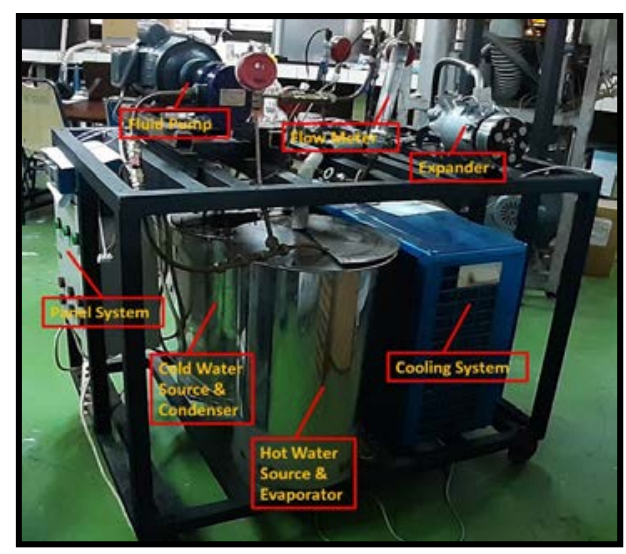

Fig. 3. ORC experiment tools

Some ORC research experiments with a variety of expanders are shown in table 1. 
Table 1. Experiments of ORC with varians expanders

\begin{tabular}{|c|c|c|c|c|c|}
\hline No & Authors & $\begin{array}{c}\text { Working } \\
\text { fluid }\end{array}$ & $\begin{array}{l}\text { Temperatur } \\
\text { range }\left({ }^{\circ} \mathrm{C}\right)\end{array}$ & $\begin{array}{c}\begin{array}{c}\text { Type of } \\
\text { expander }\end{array} \\
\end{array}$ & $\begin{array}{l}\text { Max. } \eta_{\text {exp }} \\
(\%)\end{array}$ \\
\hline 1. & Nguyen et.al. ${ }^{21)}$ & $n$-Pentane & $31-81$ & Turbine & 49.8 \\
\hline 2. & Kang et.al. ${ }^{22)}$ & R245fa & $37.4-85.4$ & Turbine & 82.2 \\
\hline 3. & Peterson et.al. ${ }^{23)}$ & R123 & $35.3-168.9$ & Scroll & 49.9 \\
\hline 4. & Kane et.al..24) & R123 & $7-165$ & Scroll & 67 \\
\hline 5. & Lemort et.al. ${ }^{25}$ & R245fa & $68.4-139$ & Scroll & 71.03 \\
\hline 6. & Quoilin et.al. ${ }^{26)}$ & R123 & $25-130$ & Scroll & 68 \\
\hline 7. & Declaye et.al..27) & R245fa & $26.6-97.5$ & Scroll & 75 \\
\hline 8. & $\begin{array}{l}\text { Manolakos } \\
\text { et.al.28) }\end{array}$ & R134a & $37-60$ & Scroll & 50 \\
\hline 9. & Saitoh et.al. ${ }^{29)}$ & R113 & $35-136$ & Scroll & 65 \\
\hline 10. & Wang et.al. ${ }^{30)}$ & R245fa & $14-115$ & $\begin{array}{c}\text { Rolling } \\
\text { piston }\end{array}$ & 45.2 \\
\hline
\end{tabular}

A scroll-type compressor branded Sanden TRSE09 model 3786 (made in Japan) was used in the ORC experiment. This compressor has not been previously used as an expander in the ORC system. The novelty of this research is shown in Table 2.

Table 2. Scroll Expander Specification

\begin{tabular}{lll}
\hline \multicolumn{1}{c}{ Parameters } & \multicolumn{2}{c}{ Specification } \\
\hline - Type & $:$ Sanden TRSE09 \\
- Model & $: 3786$ & \\
- Serial Number & $: 61595011 \mathrm{~A} 2$ \\
- Dislacement & $: 97.9$ & $\mathrm{cc} / \mathrm{rev}$ \\
- Refrigerating Capacity & $: 2.2-8.8$ & $\mathrm{~kW}$ \\
- Power Consumption & $: 1.4-4.6$ & $\mathrm{~kW}$ \\
- Discharge Pressure & $: 1.67$ & $\mathrm{MPa}$ \\
- Suction Pressure & $: 196$ & $\mathrm{MPa}$ \\
- Rotation & $: 1500$ & $\mathrm{RPM}$ \\
- Sub Cool & $: 10$ & ${ }^{0} \mathrm{C}$ \\
- Super Heat & $: 5$ & ${ }^{0} \mathrm{C}$ \\
- Electric Rating & $: 12$ & $\mathrm{Volt}$ \\
- Weight & $: 5.5$ & $\mathrm{~kg}$ \\
- Height & $: 160$ & $\mathrm{~mm}$ \\
\hline
\end{tabular}

Furthermore, the working fluid used in this ORC system is R-134a with the specifications shown in Table 3.

Table 3. Property of R-134a

\begin{tabular}{lcccc}
\hline \multicolumn{1}{c}{ Characteristics } & \multicolumn{3}{c}{ Conditions } \\
\hline Boiling Point & $:$ & 26.1 & ${ }^{\circ} \mathrm{C}$ \\
Auto-Ignition Temperature & $:$ & 770 & ${ }^{\circ} \mathrm{C}$ \\
Ozone Depletion Level & $:$ & 0 & \\
Solubility In Water $\quad:$ & $0.11 \%$ by & weight & 25 & ${ }^{\circ} \mathrm{C}$ \\
Critical Temperature & $:$ & 122 & ${ }^{\circ} \mathrm{C}$ \\
Cylinder Color Code & $:$ & Light & Blue \\
Global Warming Potential (GWP) & $:$ & \multicolumn{2}{c}{1200} \\
\hline
\end{tabular}

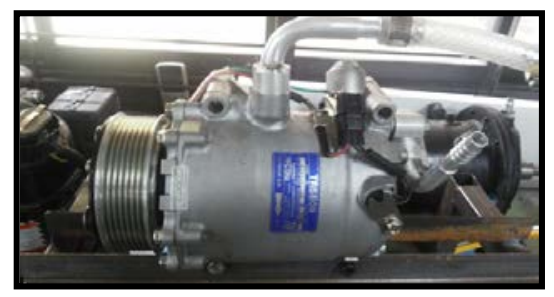

Fig. 4. Expander from Sanden TRSE09 Compressor
Figure 4 shows a car scroll compressor, which is modified into an expander as the main part for the experimental equipment. The scroll compressor has various advantages for refrigeration over the piston or screw. In addition, this type of rotational load provides excellent and lighter vapor pressure as the working fluid for the refrigerant.

\section{Result and Discussion}

Figures 5, 6, 7, 8, and 9 are graphs of the experimental results.

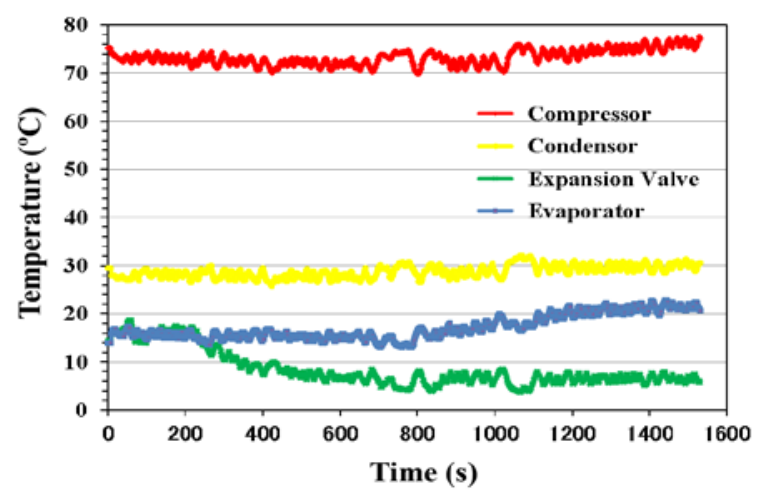

Fig. 5. Temperature and Time in Cooling

Figure 5 shows that the temperature in the cooling system changed in 4 main components, namely the evaporator, condenser, compressor, and expansion valve. The temperature change is almost constant even though there is a slight fluctuation, especially in the expansion valve, where it drops to $15{ }^{\circ} \mathrm{C}$ at 200th seconds and becomes constant.

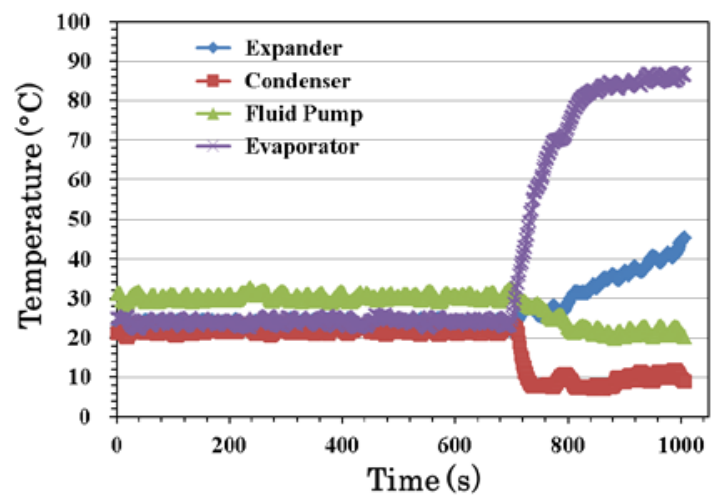

Fig. 6. Temperature and Time in ORC

Figure 6 shows the ORC component such as the evaporator, condenser, expander, and pump. At the start of the system operation, the temperature remains constant and changes at the $700^{\text {th }}$ second. Furthermore, each main component undergoes a drastic temperature change, especially in the evaporator component, with an increase of $90^{\circ} \mathrm{C}$ at 1100 th second. 


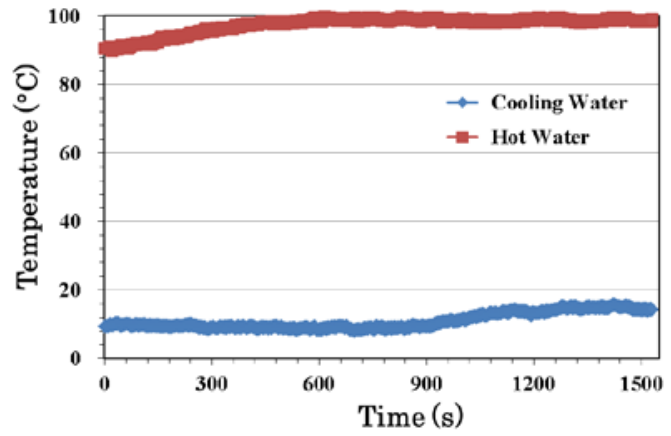

Fig. 7. Temperature and Time in Resource

Figure 7 shows that the temperatures for heating (100 $\left.{ }^{0} \mathrm{C}\right)$ and cooling water $\left(15^{\circ} \mathrm{C}\right)$ are almost constant.

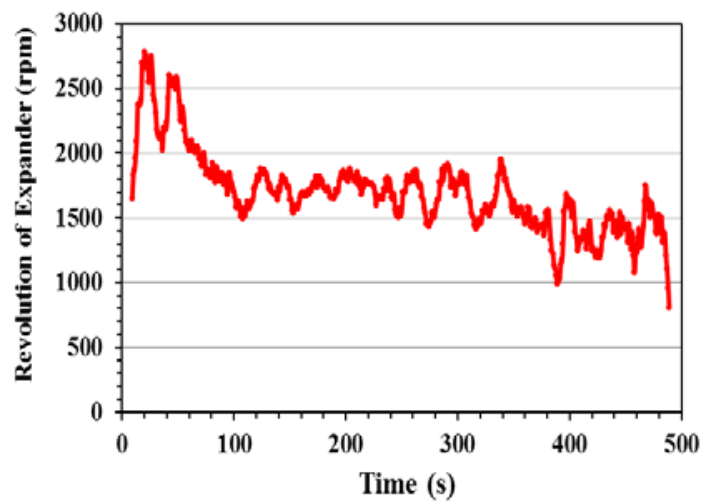

Fig. 8. Revolution and Time in Expander

Figure 8 shows the expander rotational speed. In the 10th second, the rotating speed is $1,650 \mathrm{rpm}$, and it reaches 2,750 rpm in the 20th second. Furthermore, the expander rotation stops at 480th seconds.

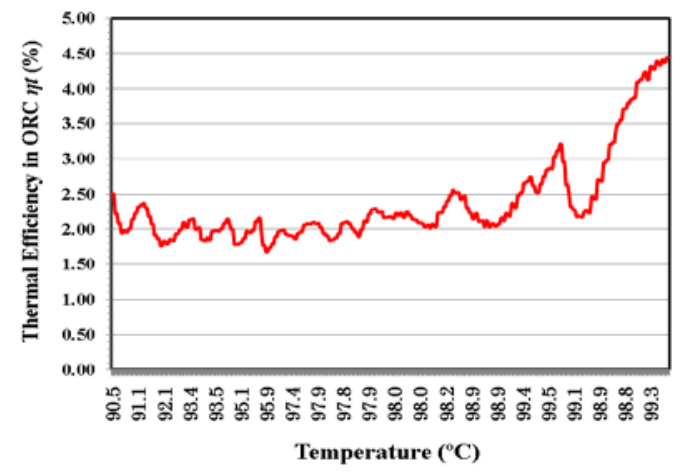

Fig. 9. Efficiency and Temperature in ORC

Figure 9 shows that the change in thermal efficiency to the temperature changes starts at a temperature of $90.5{ }^{\circ} \mathrm{C}$ with a thermal efficiency of $2.5 \%$. Furthermore, it fluctuated until it reached a final temperature of 99.8 ${ }^{0} \mathrm{C}$ with a thermal efficiency of $4.45 \%$.

\section{Conclusion}

The experiment carried out using the Sanden TRSE09 model 3786 as a car AC scroll compressor, was modified into an expander to produce the following conclusions:

1. The highest temperature at the evaporator is reached at $99.8{ }^{\circ} \mathrm{C}$ using a heater set at $100{ }^{\circ} \mathrm{C}$ and a cooler set at $7{ }^{\circ} \mathrm{C}$,

2. The thermal efficiency used in the ORC system, ranges from $2.5 \%$ to $4.45 \%$ with fluctuating system temperature conditions.

3. The expander's rpm rotation ranges from $800-2750$ rpm with rotation times from 0th to 500th seconds.

This research is useful as a reference for renewable energy development in small-scale power plants with the ORC system. In general, this power plant scale is needed in remote areas that lack electricity.

\section{Acknowledgments}

The authors are grateful to the Head of Air Cooling and Conditioning Laboratory, Department of Mechanical Engineering, Faculty of Engineering, Universitas Indonesia, for providing the opportunity to use the ORC experimental equipment.

\section{Nomenclature}

Wexp

$W p$ work of expander $(\mathrm{kW})$

Qin

Qout

$\dot{m}$

$h$

Greek symbols $\eta$ work of pump (kW) energy inlet $(\mathrm{kW})$ energy outlet $(\mathrm{kW})$ mass flow $\left(\mathrm{kg} \mathrm{s}^{-1}\right)$ specific entahlpy $\left(\mathrm{kJ} \mathrm{kg}^{-1}\right)$ thermal efficiency of ORC (-)

\section{References}

1) S. Amicabile, J.I. Lee, D. Kum, “A comprehensive design methodology of organic Rankine cycles for the waste heat recovery of automotive heavy-duty diesel engines”, Applied Thermal Engineering, 1-5 (2015). doi:10.1016/j.applthermaleng.2015.04.034.

2) S. Sonsaree, T. Asaoka, S. Jiajitsawat, H. Aguirre, K. Tanaka, “A small-scale solar Organic Rankine Cycle power plant in Thailand: Three types of non-concentrating solar collectors”, Solar Energy, 162 (January) 541-560 (2018). doi:10.1016/ j.solener.2018.01.038

3) G. Qiu, Y. Shao, J. Li, H. Liu, S.B. Riffat, "Experimental investigation of a biomass-fired ORC-based micro-CHP for domestic applications”, Fuel, 96 (January) 374-382 (2012). doi:10.1016/j. fuel.2012.01.028. 
4) W.R. Huster, D. Bongartz, A. Mitsos, "Deterministic Global Optimization of the Design of a Geothermal Organic Rankine Cycle”, Energy Procedia, 129 (September) 50-57 (2017). doi:10.1016/j.egypro.2017.09.181.

5) S. Seyedkavoosi, S. Javan, K. Kota, "Exergy-based Optimization of an Organic Rankine Cycle (ORC) for Waste Heat Recovery from an Internal Combustion Engine (ICE)”, Applied Thermal Engineering, (July) (2017). doi:10.1016/ j.applthermaleng.2017.07.124.

6) T.C. Roumpedakis, G. Loumpardis, E. Monokrousou, K. Braimakis, A. Charalampidis, S. Karellas, "Exergetic and economic analysis of a solar driven small scale ORC”, Renewable Energy, 157 (May) 1008-1024 (2020). doi:10.1016/ j.renene.2020.05.016

7) M. Preißinger, F. Heberle, D. Bruggemann, “Advanced Organic Rankine Cycle for Geothermal Application”, International Journal of Low Carbon Technologies, 8 (March) 162-168 (2013). doi:10.1093/ijlct/ctt021.

8) U. Descher, D. Bruggemann, "Fluid selection for the Organic Rankine Cycle (ORC) in Biomass Power and Heat Plants", Applied Thermal Engineering, 27 (July) 223-228 (2006). doi:10.1016/j.applthermaleng.2006.04.024.

9) M. Wei, P. Song, B. Zhao, L. Shi, Z. Wang, C. Ma, "Unsteady flow in the suction process of a scroll expander for an ORC Waste Heat Recovery System”, Applied Thermal Engineering, 78 (January) 460-470 (2015). doi:org/10.1016/ j.applthermaleng.2015.01.010.

10) Y. Wu, Z. Guo, B. Lei, L. Shen, R. Zhi, "Internal volume ratio optimization and performance analysis for Single Screw expander in small scale middle temperature ORC system”, Energy, 186 (July) 115-799 (2019). doi:10.1016/j.energy. 2019.07.129.

11) A. Giuffrida, G. Valenti, D. Palamini, L. Solazzi, "On the conceptual design of the novel balanced rolling piston expander”, Case Studies in Thermal Engineering, 12 (March) 38-46 (2018). doi:10.1016/j.csite.2018.03.003.

12) H. Rosyid, R. Koestoer, N. Putra, Nasruddin, A.A. Mohamad, Yanuar, "Sensitivity analysis of steam power plant-binary cycle”, Energy, 35 (June) 3578-3586 (2010). doi:10.1016/j.energy. 2010.04.038.

13) M. Deligant, Q. Danel, F. Bakir, "Performance assessment of a standard radial expander as turbo expander for an adapted solar concentration ORC”, Energy Procedia, 129 (September) 1085-1092 (2017). doi:10.1016/j.egypro.2017.09.200.

14) P. Platell, "Displacement Expanders for Small Scale Cogeneration”, Licentiat thesis, Department of
Machine Design, Royal Institute of Technology, (1993).

15) M. Muswar, M. Idrus Alhamid, Nasruddin, D. Rahadian, M.Z. Satria, E. Marzuki, N. Aisyah, "Design of One Combination Package Between Heat Exchangers and Heater For Organic Rankine Cycle Power Plant,” $2^{\text {st }}$ Internationational Tropical Renewable Energy Conference (i-TREC UI 2017), Bali, Indonesia. IOP Conference Series: Earth and Environmental Science, 1-7 (2018). doi:10.1088/ 1755-1315/105/1/012046.

16) M. Sharma, R. Dev, "Review and Preliminary Analysis of Organic Rankine Cycle Based on Expander Inled Temperature," Evergreen Joint Journal of Novel Carbon Resource Sciences \& Green Asia Strategy, 05 (03) (September) 22-33 (2018). doi:10.5109/1957497.

17) P. Animesh, K. Uddin, K. Thu, B.B. Saha, "Enviromental Assesment and Characteristic of Next Generation Refrigerans" Evergreen Joint Journal of Novel Carbon Resource Sciences \& Green Asia Strategy, 04 (04) (June) 8-15 (2018). doi:10.5109/1936218.

18) M.I. Alhamid, S. Bismo, I.T. Ramadhan, A. Yatim, "Study on The Effectiveness of Ozonation Technique in Preventing Scale Precipitation on Closed System Cooling Towers,” Evergreen Joint Journal of Novel Carbon Resource Sciences \& Green Asia Strategy, 06 (01) (March), 65-70 (2019). http://hdl.handle.net/2324/2321013.

19) M.A. Islam, P.Animesh, K Thu, B.B. Saha, "Study on Performance and Environmental Impact of Supermarket Refrigeration System in Japan," Evergreen Joint Journal of Novel Carbon Resource Sciences \& Green Asia Strategy, 06 (02) (June), 168-176 (2019). http://hdl.handle.net/2324/ 2321014.

20) MT. Kibria, M.A. Islam, B.B. Saha, T. Nakagawa, S. Mizuno, “Assessment of Environmental Impact for Air-Conditioning Systems in Japan Using HFC Based Refrigerants," Evergreen Joint Journal of Novel Carbon Resource Sciences \& Green Asia Strategy, 06 (03) (Sepetember), 246-253 (2019). http://hdl.handle.net/2324/ 2349301.

21) V.M. Nguyen, P.S. Doherty, S.B. Riffat, "Development of a prototype low-temperature Rankine cycle electricity generation system”, Applied Thermal Engineering, 21 (January) 169-181 (2001). prince.doherty@nottingham.ac. uk.

22) S. H. Kang, "Design and experimental study of ORC (organic Rankine cycle) and radial expander using R245fa working fluid”, Energy, 41 (March) 514-524 (2012). doi:10.1016/j.energy.2012.02. 035.

23) R. B. Peterson, H. Wang, T. Herron, "Performance of a small-scale regenerative Rankine power cycle 
employing a scroll expander”. Proceedings of the Institution of Mechanical Engineers, Part A: Journal of Power and Energy, 222 (May) JPE546 (2008). doi:10.1243/09576509JPE546.

24) M. Kane, D. Larrain, D.Favrat, Y.Allani, "Small hybrid solar power system”, Energy, 28 (July) 1427-1443 (2003). doi:10.1016/S0360-5442(03) 00127-0.

25) V. Lemort, S. Declaye, S. Quoilin, Experimental characterization of a hermetic scroll expander for use in a micro-scale Rankine cycle. Proceedings of the Institution of Mechanical Engineers, Part A: Journal of Power and Energy, (May) 126-136 (2011). doi:10.1177/0957650911413840.

26) S. Quoilin, V. Lemort, J. Lebrun, "Experimental study and modeling of an Organic Rankine Cycle using scroll expander”, Applied Energy, 87 (August) 1260 - 1268 (2009). doi:10.1016/ j.apenergy.2009.06.026.

27) S. Declaye, S. Quoilin, L. Guillaume, V. Lemort, "Experimental study on an open-drive scroll expander integrated into an ORC (Organic Rankine Cycle) system with R245fa as working fluid”, Energy, 55 (May) 173-183 (2013). doi:10.1016/ j.energy.2013.04.003.

28) D. Manolakos, G. Kosmadakis, S. Kyritsis, G. Papadakis, "Identification of behaviour and evaluation of performance of small scale, low-temperature Organic Rankine Cycle system coupled with a RO desalination unit”, Energy, 34 (April) 6767-774 (2009). doi:10.1016/j.energy. 2009.02.008.

29) T. Saitoh, N. Yamada, S. Wakashima, "Solar Rankine Cycle System Using Scroll Expander”, Journal of Environment and Engineering, 2 (April) 708-719 (2007). doi;10.1299/jee.2.708.

30) X. D. Wang, L. Zhao, J. L.Wang, W. Z. Zhang, X. Z. Zhao, W. Wu, "Performance evaluation of a low-temperature solar Rankine cycle system utilizing R245fa”, Solar Energy, 84 (January) 3353-364 (2010). doi:10.1016/j.solener.2009. 11.004 . 